\title{
Radon risk in carcinogenesis what prevention
}

\section{Mauro Mazzotta*}

MD, Occupational Medicine, Salento University, 73100 Lecce, Italy
Received: 24 August, 2020

Accepted: 04 September, 2020

Published: 05 September, 2020

*Corresponding author: Mauro Mazzotta, MD, Occupational Medicine, Salento University, 73100 Lecce, Italy, E-mail: mazzotta.mauro@libero.it

https://www.peertechz.com
In environments, exposure to 222radon is to be considered chronic and the effects are based on cellular, subcellular and molecular radiotoxicological mechanisms [1]; We start from the alpha particles and their decay products, but the action continues through the access into the pulmonary tract with aerosols and environmental polluting particles (size 0.0005$100 \mu \mathrm{m}$ in diameter) [2].

The action consists of an immunological reaction based on macrophages and involvement of the lymphatic system. Alpha particles react with DNA, create oxidative stress and radiolysis, but the radioactive effects also continue due to the gamma energy of $14 \mathrm{Bi}[3,4]$. Many studies prove to be aimed at clinical evidence deriving from the action of radon and in predicting diseases such as lung cancer [5-7], as well as to indicate which carcinogenetic theory is applicable, it is conceivable that 222radon alters communication between cells and their microenvironment, because the biophysical and molecular messages of induction processes are no longer recognized $[8,9]$; US-EPA [7] indicates $13 \%$ of lung cancers to be attributed to radon in the general population, but if the exposure is in the work environment this disease becomes occupational. Preventive action must certainly identify environments with objectives of improving ventilation and useful and necessary building rules and regular monitoring. The concomitance of COPD in the exposure to radon and the decay product cannot be excluded [10]. The most exposed subjects must be considered with particular attention, at the same time discouraging the habit of active and passive smoking, activating where necessary high-resolution CTA, periodic cytopathological examination, spirometry and alveolar-capillary diffusion, detection of allergic diseases. The environment requires adequate environmental changes, continuous ventilation, environmental remediation of fungi and bacteria. The analysis of lung histological types also predicts that in the case of primary lung tumors, there is a higher incidence of the histological type of NSLC (Non small cell Lung Cancer) "Lung adenocarcinomas" of the order of $43 \%$ in smokers and $45 \%$ in non-smokers, compared to "squamous epidermoid carcinoma" equal to $42 \%$ in smokers and $33 \%$ in non-smokers. What remains about $20 \%$ includes small cell lung cancer (17\% SCLC), carcinoid, sarcoma and other histoptypes [11].

Many studies in monitoring of miRNA in pulmonary cancer are ongoing and bode well, miRNAs profile were changed when exposed to radon in cellular culture [12].

The latency time is very long necessary for the appearance of these respiratory pathologies determines an etiological uncertainty about the origin of the pulmonary pathology. Some studies on the respiratory system show pulmonary hypertension, hypoxigenation, cor pulmonale [4] arouse attention even if a true association between residential 222radon and mortality from non-malignant respiratory diseases needs to be further investigated (Cancer Prevention Study-II) indicates a positive linear trend in COPD mortality by increasing categories of radon concentrations $(p<0.05)$ [1316].

Recommendation to maintain the $300 \mathrm{~Bq} \mathrm{~m}^{-3}$ levels in the indoor phase, which were reviewed in 2014 at the lower level reasonably achievable in the range $100-300 \mathrm{~Bq} \mathrm{~m}^{-3}$ [17].

\section{References}

1. (2018) ICRP Summary of ICRP Recommendations on Radon ref 4836-97568598. Link: https://bit.ly/2Z6CruH

2. (1994) ICRP Publication 66 Human Respiratory Tract Model for Radiological Protection ICRP Publication 66 ICRP 24. Link: https://bit.ly/2QSVtAl

3. Bellotti E, Broggini C, Di Carlo G, Laubenstein M, Menegazzo R (2015) Precise measurement of the 222Rn half-life: a probe to monitor the stability of radioactivity. Physics Letters B 743: 526-530. Link: https://bit.ly/2Z7Yh17

4. Victor AE, Attilio RD, Reuben DS, Joseph QJ, Thomas CV (1998) Chronic Diffuse Interstitial Fibrosis of the Lung in Uranium Miners $\mathrm{J}$ Occup Environ Med 40: 460-474. Link: https://bit.ly/2F645kk

5. Hunter N, Muirhead CR, Bochicchio F, Haylock RGE (2015) Calculation 
of lifetime lung cancer risks associated with radon exposure, based on various models and exposure scenarios. J Radiol Prot 35: 539. Link: https://bit.ly/2QPFaEu

6. National Academy of Sciences, Washington, D.C. Biological Effects of Ionizing Radiation (BEIR) VI Report: The Health Effects of Exposure to Indoor Radon,1998.

7. U.S. Environmental Protection Agency Office of Radiation and Indoor Air EPA assessment of risks from radon in homes; United States Environmental Protection Agency: Washington, DC, USA, 2003. Link: https://bit.ly/3gYZyxi

8. Bizzarri M, Cucina A (2014) Tumor and the microenvironment: a chance to reframe the paradigm of carcinogenesis?. Biomed Res Int 2014. Link: https://bit.ly/31Wz2QV

9. Sonnenschein C, Soto AM (2008) Theories of carcinogenesis: an emerging perspective. Semin Cancer Biol 18: 372-377. Link: https://bit.ly/3IZqzVo

10. Kendall GM, Smith TJ (2002) Doses to organs and tissues from radon and its decay products. J Radiol Prot 22: 389-406. Link: https://bit.ly/3jJD4Ch

11. Bryant A, Cerfolio RJ (2007) Differences in epidemiology, histology, and survival between cigarette smokers and never-smokers who develop nonsmall cell lung cancer. Chest 132: 185-192. Link: https://bit.ly/3boW3z8
12. Bersimbaev R, Pulliero A, Bulgakova O, Asia K, Aripova A, et al. (2020) Radon Biomonitoring and microRNA in Lung Cancer Int J Mol Sci 21: 2154. Link: https://bit.ly/2F0b52x

13. Jessica SD, Quynh-Thu L, Wakelee HA (2006) Lung cancer in women: exploring sex differences in susceptibility, biology, and therapeutic response. Clinica Lung Cancer 8: 22-29. Link: https://bit.ly/2GuNDLm

14. Turner MC, Krewski D.I, Chen Y, Arden C (2012) Pope Radon and COPD mortality in the American Cancer Society Cohort Eur Respir J 39: 1113-1119. Link: https://bit.ly/32QX53a

15. Robertson A, Allen J, Laney R, Curnow A (2013) The Cellular and Molecular Carcinogenic Effects of Radon Exposure: A Review Int J Mol Sci 14: 14024 14063. Link: https://bit.ly/3ibKoGN

16. Ruano-Ravina A, Torres-Durán M, Kelsey KT, Parente-Lamelas I, LeiroFernández V, et al. (2016) Residential radon, EGFR mutations and ALK alterations in never-smoking lung cancer cases. Eur Respir J 48: 1462-1470. Link: https://bit.ly/32VseTd

17. Lecomte JF, Solomon S, Takala J, Jung T, Strand P, et al. (2014) Radiological Protection against Radon Exposure. ICRP 126 Ann ICRP 43.

\section{Discover a bigger Impact and Visibility of your article publication with}

\section{Peertechz Publications}

Copyright: () 2020 Mazzotta M. This is an open-access article distributed under the terms of the Creative Commons Attribution License, which permits unrestricted use, distribution, and reproduction in any medium, provided the original author and source are credited. 